\title{
Vendor Selection Process Document
}

National Cancer Institute

\section{Source}

National Cancer Institute. Vendor Selection Process Document. NCI Thesaurus. Code C115747.

Records describing the selection process of a vendor. 